\title{
PENGARUH PEMBERIAN JUS TOMAT TERHADAP KADAR GLUKOSA DARAH PADA PREDIABETES
}

\author{
Yuniarti Dwi Astuti, Hesti Murwani R. ${ }^{*}$ \\ Program Studi Ilmu Gizi Fakultas Kedokteran Universitas Diponegoro \\ Jl.Dr.Sutomo No.14, Semarang, Telp (024) 8453708, Email : gizifk@undip.ac.id
}

\begin{abstract}
Background : Prediabetes is a condition in which a person's blood glucose level is between normal and diabetic levels. Diet is an effective way to lower blood glucose levels. Tomato juice is a drink that is associated with the decrease of blood glucose levels. This study were designed to prove the effect of tomato juice on blood glucose levels in prediabetes..

Method : This study was pre experiment with one group pre test-post test design. The subjects were people in Sendangguwo Semarang taken by consecutive sampling. Total subjects was 21 people. Each sample was given 200 $\mathrm{ml}$ of tomato juice from 180 gram red tomato Lycopersicum commune that are blanched with water at a temperature of 70-90 ${ }^{\circ} \mathrm{C}$ for 10 minutes and then blended and filtered. Tomato juice intervention is given for 3 weeks. Fasting blood glucose level was measured one day before and one day after the intervention using the spectrophotometric method. During the intervention, intake data were obtained by the method of food recall $3 \times 24$ hours. Data were analyzed using Shapiro Wilk dan paired t-test.

Result : There were a decrease in fasting blood glucose levels of $9.00 \mathrm{mg} / \mathrm{dl}(7.64 \%)$ after being given tomato juice for 3 weeks.

Conclusion : The statistical test showed there are significant differences on fasting blood glucose levels decrease before and after being given tomato juice.
\end{abstract}

Key word : tomato juice; blood glucose; prediabetes

\begin{abstract}
ABSTRAK
Latar Belakang : Prediabetes merupakan kondisi dimana kadar glukosa darah seseorang berada diantara kadar normal dan diabetes. Pengaturan diet merupakan cara efektif untuk menurunkan kadar glukosa darah. Jus Tomat merupakan salah satu bahan minuman yang dihubungkan dengan penurunan kadar glukosa darah. Penelitian ini bertujuan untuk membuktikan pengaruh pemberian jus tomat terhadap kadar glukosa darah pada prediabetes.

Metode : Penelitian ini merupakan penelitian pra eksperimen dengan rancangan one group pre test-post test design. Subjek penelitian adalah warga Kelurahan Sendangguwo Semarang yang diambil secara consecutive sampling. Besar sampel adalah 21 orang. Tiap sampel diberi jus tomat sebanyak $200 \mathrm{ml}$ yang berasal dari 180 gram tomat merah jenis Lycopersicum commune yang di-blanching dengan air pada suhu $70-90^{\circ} \mathrm{C}$ selama 10 menit kemudian diblender dan disaring. Intervensi jus tomat diberikan selama 3 minggu. Kadar glukosa darah puasa diukur satu hari sebelum dan satu hari setelah intervensi dengan menggunakan metode spektrofotometri. Selama intervensi, asupan makan diperoleh dengan metode food recall $3 \times 24$ jam. Data yang diperoleh dianalisis menggunakan uji Shapiro Wilk dan paired t- test.

Hasil : Terjadi penurunan kadar glukosa darah puasa sebesar 9,00 mg/dl (7,64\%) setelah pemberian jus tomat selama 3 minggu.

Simpulan : Uji statistik menunjukkan terdapat perbedaan bermakna terhadap penurunan kadar glukosa darah puasa sebelum dan setelah pemberian jus tomat.
\end{abstract}

Kata kunci : jus tomat; kadar glukosa darah; prediabetes

\section{PENDAHULUAN}

Prediabetes adalah kondisi dimana kadar gula darah seseorang berada diantara kadar normal dan diabetes. ${ }^{1}$ Penderita prediabetes di Indonesia sebanyak 57 juta orang dan terus mengalami peningkatan. Prediabetes merupakan faktor risiko yang kuat terhadap kejadian diabetes melitus. Apabila tidak dikontrol dengan baik, kondisi prediabetes dapat meningkat menjadi diabetes tipe 2 dalam kurun waktu 5-10 tahun. ${ }^{2}$

Prediabetes terletak diantara kedua keadaan yaitu, Impaired Fasting Glucose (IFG) dan Impaired Glucose Tolerance (IGT). IFG merupakan keadaan dimana kadar glukosa darah puasa seseorang sekitar $100-125 \mathrm{mg} / \mathrm{dl}$ dan IGT merupakan keadaan dimana kadar glukosa darah seseorang 2 jam setelah mengkonsumsi 75 gram 
glukosa per oral berada diantara $140-199 \mathrm{mg} / \mathrm{dl}$. Berdasarkan penelitian, risiko IGT menjadi diabetes lebih besar dibanding IFG. ${ }^{3}$ Progresivitas IGT menjadi diabetes $6-10 \%$ pertahun. ${ }^{4}$ Kondisi prediabetes dapat diperbaiki dengan pengaturan makanan dan melakukan olahraga secara teratur. ${ }^{5}$ Hasil sebuah penelitian menunjukkan bahwa $15,5 \%$ kejadian prediabetes lebih besar tejadi pada wanita dibanding pria karena secara fisik wanita memiliki peluang peningkatan BMI (Body Mass Index) lebih besar. ${ }^{6}$ Usia yang biasanya mengalami peningkatan glukosa darah adalah setelah 40 tahun karena pada usia tersebut terjadi perubahan sel beta pankreas yang menghasilkan hormon insulin. ${ }^{7}$

Pengaturan makanan memberikan pengaruh yang efektif terhadap penurunan kadar glukosa darah. Survei Pemeriksaan Gizi dan Kesehatan Nasional AS menemukan adanya pengaruh makanan kaya karotenoid terhadap kadar glukosa darah para pengidap diabetes. ${ }^{6}$ Salah satu bahan makanan yang dihubungkan dengan penurunan kadar glukosa darah yaitu tomat. ${ }^{7,8,9}$ Tomat memiliki zat aktif utama yang disebut dengan likopen. Berbagai penelitian ilmiah menunjukkan, likopen merupakan kelompok karotenoid yang tidak hanya penting sebagai pigmen pemberi warna merah, tetapi juga sangat bermanfaat bagi kesehatan, yaitu menurunkan glukosa darah, memperlambat kanker prostat, dan mencegah osteoporosis. ${ }^{10}$ Kandungan likopen pada tomat yang telah melalui proses pemanasan akan lebih banyak dan lebih mudah diserap tubuh dibandingkan dengan tomat segar. ${ }^{11}$ Pada pembentukan likopen, suhu mempunyai peranan yang penting, jika suhu naik maka likopen yang terbentuk akan semakin banyak . ${ }^{10,11}$ Likopen dalam tomat akan lebih mudah diserap tubuh jika diproses menjadi olahan seperti jus. ${ }^{7}$ Kandungan likopen pada $100 \mathrm{~g}$ tomat yang dibuat jus sebanyak $12,8 \mathrm{mg}$ sedangkan pada $100 \mathrm{~g}$ tomat segar sebanyak 5,8 mg. ${ }^{11}$ Likopen dapat menurunkan glukosa darah dengan cara menurunkan resistensi hormon insulin, sehingga toleransi sel terhadap glukosa meningkat sehingga kelebihan kadar gula darah dapat ditanggulangi. ${ }^{7}$ Tomat yang digunakan sebanyak 180 gram dengan kandungan likopen 23 gram dapat menurunkan kadar glukosa darah sebesar $1,2 \mathrm{mg} / \mathrm{dl}$ pada penderita diabetes selama 3 hari. ${ }^{10}$

Berdasarkan data Puskesmas Sendangguwo, Semarang kunjungan prediabetes terus mengalami peningkatan. Pada tahun 2009 didapatkan 215 kunjungan pasien prediabetes sedangkan pada tahun 2010 meningkat menjadi 347 kunjungan.
Penelitian tentang konsumsi jus tomat terhadap kadar glukosa darah penderita Diabetes Melitus Tipe 2 pernah dilakukan. Namun, penelitian tentang konsumsi jus tomat terhadap kadar glukosa darah pada subjek prediabetes belum pernah dilakukan. Selain itu, prediabetes tidak mengkonsumsi obat-obatan sehingga diharapkan jus tomat yang diberikan memiliki pengaruh yang signifikan. Hal inilah yang mendorong peneliti untuk melakukan penelitian tentang pengaruh jus tomat terhadap kadar glukosa darah pada subjek prediabetes.

\section{METODE}

Penelitian dilakukan di wilayah kerja Puskesmas Sendangguwo Semarang pada bulan Juni 2012. Desain penelitian adalah pre eksperimen dengan rancangan one group pre testpost test design. Penentuan subyek penelitian menggunakan metode consecutive sampling. Sebanyak 57 orang bersedia diambil darahnya untuk proses skrining awal dan diperoleh sebanyak 23 orang yang memenuhi kriteria inklusi untuk menjadi subyek penelitian yang semuanya dijadikan 1 kelompok. Kriteria inklusi subjek penelitian antara lain wanita usia 40-50 tahun yang belum menopause, kadar glukosa darah puasa $100-$ $125 \mathrm{mg} / \mathrm{dl}$, IMT $\geq 23 \mathrm{~kg} / \mathrm{m}^{2}$, tidak mengkonsumsi obat-obatan yang mengendalikan kadar glukosa darah dan tidak mengkonsumsi alkohol.

Prosedur pertama dalam penelitian ini adalah memberikan penjelasan tentang maksud penelitian, metode penelitian yang digunakan, risiko dan ketidaknyamanan yang akan dialami serta keuntungan yang diperoleh subjek penelitian. Subjek yang bersedia menjadi sampel diminta menandatangani informed consent, selanjutnya dilakukan pengukuran berat badan (BB) dan tinggi badan (TB) untuk mengetahui IMT nya, pengukuran kadar glukosa darah puasa dan diberikan penyuluhan.

Subjek diberi intervensi berupa jus tomat. Jus tomat diberikan pada setiap subjek sebanyak $200 \mathrm{ml}$ yang berasal dari $180 \mathrm{~g}$ tomat tanpa tambahan gula dan air dengan frekuensi 1x/hari selama 21 hari. Pemberian jus tomat dilakukan secara langsung oleh peneliti dan setiap subjek harus meminumnya di depan peneliti hingga habis $100 \%$. Kepatuhan mengkonsumsi jus tomat dipantau dengan formulir daya terima. Pada hari ke-22 dilakukan pengukuran kembali kadar glukosa darah puasa sebagai data akhir.

Data yang dikumpulkan berupa data primer meliputi data umum subjek, data asupan makan, 
dan data tingkat kepatuhan yang dikumpulkan melalui wawancara. Kemudian data yang dikumpulkan melalui pengukuran antropometri adalah data berat badan yang diperoleh melalui penimbangan dengan timbangan digital yang tingkat ketelitiannya $0,1 \mathrm{~kg}$ dan data tinggi badan yang diperoleh melalui pengukuran dengan mikrotoa yang tingkat ketelitiannya $0,1 \mathrm{~cm}$. Sedangkan data biokimiawi yaitu kadar glukosa darah puasa dilakukan oleh petugas puskesmas Sendangguwo dengan menggunakan metode spektrofotometri.

Variabel bebas adalah jus tomat yang berasal dari tomat jenis Lycopersicum commune yang berwarna merah dengan usia panen 70-100 hari diblanching dengan air pada suhu $70-90^{\circ} \mathrm{C}$ selama 10 menit kemudian diblender dan disaring. Variabel terikat adalah kadar glukosa darah puasa yang diambil melalui pembuluh vena mediana cubiti dengan metode spektrofotometri setelah subjek berpuasa selama 8 jam. Sedangkan variabel perancu adalah asupan makan yaitu rata-rata makan subjek penelitian selama penelitian yang diperoleh dengan metode food recall $21 \times 24$ jam dan diolah menggunakan nutrisurvey.

Data yang diperoleh dianalisis secara statistik. Analisis deskriptif digunakan untuk melihat gambaran karakteristik subjek. Uji normalitas data glukosa darah puasa sebelum dan setelah perlakuan menggunakan uji Shapiro-Wilk. Data berdistribusi normal sehingga untuk mengetahui perbedaan kadar glukosa darah puasa sebelum dan setelah pemberian jus tomat menggunakan uji paired $t$ test. Hubungan antara asupan makan selama intervensi terhadap kadar glukosa darah menggunakan uji korelasi pearson karena data berdistribusi normal.

\section{HASIL PENELITIAN}

Penelitian dilaksanakan di wilayah Puskesmas Sendangguwo Semarang pada bulan Juni 2012. Sebanyak 23 orang memiliki kriteria inklusi untuk menjadi subjek penelitian. Selama penelitian 2 orang drop out karena tidak mematuhi prosedur penelitian sehingga jumlah akhir subjek penelitian adalah 21 orang.

Tabel 1. Karakteristik Awal Subjek Penelitian

\begin{tabular}{|c|c|c|c|}
\hline \multirow{2}{*}{ Karakteristik Subjek } & \multicolumn{3}{|c|}{ Perlakuan (n=21) } \\
\hline & $\mathrm{N}$ & $\%$ & Rerata \pm SB \\
\hline \multicolumn{4}{|l|}{ Kelompok Usia } \\
\hline 40-45 tahun & 13 & 61,9 & $45,19 \pm 2,82$ \\
\hline 46-50 tahun & 8 & 38,1 & \\
\hline \multicolumn{4}{|l|}{$\mathrm{IMT}^{5}$} \\
\hline Overweight $\left(23-24,9 \mathrm{~kg} / \mathrm{m}^{2}\right)$ & 6 & 28,6 & $27,37 \pm 3,50$ \\
\hline Obesitas $\left(>25 \mathrm{~kg} / \mathrm{m}^{2}\right)$ & 15 & 76,1 & \\
\hline \multicolumn{4}{|l|}{ Aktifitas Fisik $^{12}$} \\
\hline Ringan & 16 & 76,19 & $2161,50 \pm 226,46$ \\
\hline Sedang & 5 & 23,8 & \\
\hline \multicolumn{4}{|l|}{ Tingkat Pendidikan } \\
\hline Tamat SD & 8 & 38 & \\
\hline Tamat SMP & 6 & 28,6 & $(-)$ \\
\hline Tamat SMA & 6 & 28,6 & \\
\hline Tamat Perguruan Tinggi & 1 & 4,8 & \\
\hline \multicolumn{4}{|l|}{ Jenis Pekerjaan } \\
\hline Tidak bekerja & 16 & 76,1 & \\
\hline Wiraswasta & 2 & 9,5 & $(-)$ \\
\hline Pegawai swasta & 1 & 4,8 & \\
\hline Pegawai negeri & 1 & 4,8 & \\
\hline Buruh cuci & 1 & 4,8 & \\
\hline
\end{tabular}


Tabel 1 menunjukkan subjek penelitian sebagian besar berada pada kelompok usia 40-45 tahun (61,9\%), indeks massa tubuh (IMT) sebagian besar tergolong obesitas $(71,4 \%)$, tingkat aktifitas tergolong ringan $(76,19 \%)$, pendidikan sebagian besar tamat Sekolah Dasar (38\%), dan sebagian besar tidak bekerja $(76,1 \%)$. Rerata usia adalah
45,19 tahun, IMT $27,37 \mathrm{~kg} / \mathrm{m}^{3}$ dan aktifitas fisik 2161,50 kal. Pada variabel usia, IMT dan aktifitas fisik tidak perlu dilakukan uji homogenitas karena kesamaan varians tidak menjadi syarat untuk uji kelompok yang berpasangan. ${ }^{13}$

\section{Perbedaan IMT Sebelum dan Sesudah Intervensi}

Tabel 2. Perbedaan IMT Sebelum dan Sesudah Intervensi

\begin{tabular}{lcl}
\hline \multicolumn{1}{c}{ Variabel } & Rerata+SB & $p^{\mathrm{a}}$ \\
\hline IMT pre & $27,37 \pm 3,50$ & 0,057 \\
IMT post & $27,04 \pm 3,60$ & \\
\hline
\end{tabular}

Keterangan : ${ }^{\mathrm{a}}$ (Paired t test)

Tabel 2 menunjukkan tidak adanya perbedaan IMT sebelum dan sesudah intervensi. Hal ini ditunjukkan dengan $\mathrm{p}>0,05$.

Asupan Makan Sebelum dan Selama Intervensi
Faktor yang dapat mempengaruhi kadar glukosa darah adalah asupan energi, protein, serat, karbohidrat, dan lemak. Perbedaan rerata asupan makan 3 hari sebelum dan selama intervensi terlihat pada tabel 2 .

Tabel 3. Rerata asupan makan sebelum dan selama intervensi

\begin{tabular}{llll}
\hline & \multicolumn{2}{c}{ Perlakuan $(\mathrm{n}=21)$} & \multirow{2}{*}{$p^{\text {a }}$} \\
\cline { 2 - 3 } \multicolumn{1}{c}{ Asupan } & \multicolumn{1}{c}{ Sebelum intervensi } & \multicolumn{1}{c}{ Selama intervensi } & \\
\cline { 2 - 3 } & Rerata \pm SB & Rerata \pm SB & 0,564 \\
Energi (kkal) & $1585,5 \pm 292,4$ & $1447,5 \pm 265,48$ & 0,548 \\
Protein (g) & $30,3 \pm 11,74$ & $46,63 \pm 9,2$ & 0,215 \\
Serat $(\mathrm{g})$ & $10,12 \pm 4,13$ & $11,39 \pm 3,6$ & 0,837 \\
Karbohidrat (g) & $221,57 \pm 48,74$ & $209,1 \pm 53,3$ & 0,943 \\
Lemak (g) & $46,63 \pm 16,8$ & $36,30 \pm 13,16$ & \\
\hline
\end{tabular}

Keterangan : ${ }^{\mathrm{a}}$ (Paired $t$ - test $)$

Tabel 3 menunjukkan bahwa rerata asupan energi, karbohidrat, dan lemak pada sebelum intervensi lebih tinggi daripada selama intervensi. Sedangkan asupan protein dan serat sebelum intervensi lebih rendah daripada selama intervensi. Uji beda menunjukkan tidak terdapat perbedaan rerata asupan energi, protein, serat, karbohidrat, dan lemak pada sebelum dan selama intervensi.

Korelasi kadar GDP dengan Asupan Makan Selama Intervensi

Hubungan antara kadar glukosa darah dengan asupan makan selama intervensi ditampilkan pada tabel dibawah ini.

Tabel 4. Korelasi kadar glukosa darah dengan asupan makan selama intervensi

\begin{tabular}{|c|c|c|c|c|c|}
\hline $\begin{array}{l}\text { Kadar } \\
\text { GDP }\end{array}$ & Energi & Karbohidrat & Lemak & Protein & Serat \\
\hline$r$ & $-0,565$ & -0.075 & -0.281 & -0.525 & -0.137 \\
\hline$P^{\mathrm{b}}$ & 0.008 & 0.170 & 0.178 & 0.254 & 0.052 \\
\hline
\end{tabular}

Keterangan : ${ }^{b}(\mathrm{Uji}$ Korelasi Pearson $)$

Tabel 4 menunjukkan adanya korelasi negatif yang kuat antara penurunan kadar glukosa darah dengan peningkatan asupan energi. Hal ini ditunjukkan dengan nilai $\mathrm{r}$ sebesar -0.565 , artinya semakin tinggi asupan energi maka GDP semakin turun. Pada uji ini terdapat hubungan yang signifikan antara penurunan kadar glukosa darah dengan peningkatan asupan energi selama intervensi $(p<0,05)$. 
Korelasi IMT setelah intervensi dengan GDP setelah intervensi
Hubungan antara IMT setelah intervensi dengan GDP setelah intervensi ditampilkan pada tabel dibawah ini.

\begin{tabular}{ccc}
\hline Kadar GDP & & IMT post \\
\hline & $\mathrm{r}$ & 0.195 \\
& $P^{\mathrm{b}}$ & 0.396
\end{tabular}

Keterangan: ${ }^{\mathrm{b}}$ (Uji Korelasi Pearson)

Tabel 5 menunjukkan adanya korelasi positif yang sangat lemah antara IMT setelah intervensi dengan GDP setelah intervensi. Hal ini ditunjukkan dengan nilai $r$ sebesar 0.195 , artinya semakin rendah nilai IMT maka GDP akan semakin rendah pula. Pada uji ini tidak terdapat hubungan yang signifikan antara IMT setelah intervensi dengan GDP setelah intervensi $(p<0,05)$.

\section{Daya Terima Jus Tomat}

Selama penelitian setiap subjek langsung mengkonsumsi jus tomat yang diberikan oleh peneliti. Namun pada penelitian ini ada 2 orang yang mengalami drop out. Satu orang karena hanya menghabiskan $110 \mathrm{ml}$ jus tomat sebanyak 1 kali dan 1 orang karena sakit typus pada hari ke 14 penelitian. Rerata asupan jus tomat adalah 195,7 $\mathrm{ml}$ per hari, dengan persentase jus tomat yang terminum adalah $97,85 \%$.

Perbedaan Kadar Glukosa Darah Puasa Sebelum dan Sesudah Intervensi

Tabel 6. Perbedaan GDP sebelum dan setelah intervensi

\begin{tabular}{lll}
\hline \multicolumn{1}{c}{ Variabel } & \multicolumn{1}{c}{ Perlakuan $(\mathrm{n}=21)$} & $p^{\mathrm{a}}$ \\
\cline { 2 - 3 } & \multicolumn{1}{c}{ Rerata \pm SB } & \\
\hline GDP Pre & $112,76 \pm 6,715$ & 0,001 \\
GDP Post & $103,76 \pm 6,971$ & \\
$\Delta$ GDP & $-9,00 \pm 10,17$ & \\
\hline
\end{tabular}

Keterangan : ${ }^{\mathrm{a}}($ Paired $t$ test $)$

Tabel 6 menunjukkan adanya penurunan kadar glukosa darah puasa setelah pemberian jus tomat selama 3 minggu. Penurunan GDP ditunjukan dengan rerata $9,00 \mathrm{mg} / \mathrm{dl}(7,64 \%)$. Pada uji beda terdapat perbedaan bermakna antara GDP sebelum dan sesudah intervensi $(\mathrm{p}=0,001)$. Sedangkan GDP pada subjek yang tidak menghabiskan jus tomat mengalami penurunan sebesar $4 \mathrm{mg} / \mathrm{dl}$.

\section{PEMBAHASAN}

Subjek penelitian pada penelitian ini semuanya adalah wanita. Wanita mempunyai risiko mengalami prediabetes lebih tinggi dibanding pria. Hal ini disebabkan persentase lemak tubuh wanita lebih tinggi dibanding pria. Komposisi lemak yang tinggi dapat berkaitan dengan risiko gangguan toleransi glukosa. ${ }^{14}$

Subjek penelitian dipilih usia $\geq 40$ tahun karena pada usia ini biasanya mengalami penurunan produksi insulin. Penurunan produksi insulin mengakibatkan berkurangnya jumlah glukosa yang masuk ke dalam sel sehingga glukosa akan tetap berada pada dalam pembuluh darah sehingga menyebabkan kadar glukosa darah meningkat. ${ }^{15}$ Rentang usia yang dipilih adalah 40 50 tahun dan belum mengalami menopause. Hormon estrogen dan progesteron dapat mempengaruhi sel-sel dalam tubuh merespon insulin. Setelah menopause, terjadi penurunan tingkat hormon estrogen dan progesteron sehingga dapat memicu peningkatan kadar glukosa darah. ${ }^{16}$

Sebagian besar $(71,4 \%)$ subjek penelitian tergolong obesitas. ${ }^{17}$ Obesitas merupakan faktor risiko utama terjadinya DM. $^{6}$ Persentase lemak tubuh yang berlebih dapat menyebabkan respon sel beta terhadap glukosa darah menjadi berkurang, selain itu reseptor insulin pada target sel di seluruh tubuh kurang sensitif dan jumlahnya berkurang sehingga insulin dalam darah tidak dapat 
dimanfaatkan. ${ }^{18}$ Penurunan berat badan merupakan salah satu cara untuk menurunkan risiko prediabetes maupun DM. Monitoring terhadap kadar glukosa darah, asupan makan, dan aktifitas fisik juga diperlukan untuk menjaga kestabilan kadar glukosa darah. ${ }^{19}$

Aktifitas fisik sebagian besar subjek penelitian $(76,19 \%)$ mempunyai tingkat aktifitas ringan. Kurangnya aktifitas fisik dikaitkan dengan kejadian prediabetes dan DM. ${ }^{20}$ Aktifitas fisik yang kurang mengakibatkan sensitivitas dari reseptor dan insulin semakin menurun sehingga glukosa darah yang dipakai untuk metabolisme energi semakin sedikit. $^{21}$ Salah satu cara untuk meningkatkan aktifitas fisik yaitu dengan berolahraga. Sebanyak $23,8 \%$ subjek penelitian mempunyai kebiasaan olahraga 3 kali seminggu selama 15 menit. Olahraga yang dilakukan secara teratur yaitu 3-4 kali seminggu selama 30 menit menyebabkan peningkatan pemakaian glukosa darah oleh otot yang aktif sehingga secara langsung dapat menyebabkan penurunan kadar lemak tubuh, mengontrol kadar glukosa darah, dan memperbaiki sensitivitas insulin. ${ }^{22}$

Selama intervensi terdapat beberapa subjek yang mengalami peningkatan dan penurunan $\mathrm{BB}$ sehingga terjadi perubahan perhitungan IMT. Hasil uji statistik menunjukkan tidak terdapat perbedaan bermakna antara IMT sebelum dan setelah intervensi. Sedangkan pada uji korelasi menunjukkan adanya korelasi positif yang sangat lemah antara IMT setelah intervensi dengan GDP setelah intervensi. Hal ini ditunjukkan dengan nilai r sebesar 0.195.

Asupan makan berpengaruh terhadap kadar glukosa darah. Pada saat sebelum intervensi, rerata asupan energi, karbohidrat, dan lemak lebih tinggi daripada selama intervensi sedangkan asupan protein dan serat lebih rendah daripada selama intervensi. Hal ini disebabkan karena sebagian besar subjek selama pemberian jus tomat melakukan perubahan pola makan dan mengurangi konsumsi gula sederhana. Pengaturan pola makan merupakan cara efektif untuk menurunkan kadar glukosa darah. ${ }^{1}$

Hasil uji korelasi variabel perancu menunjukkan asupan energi selama intervensi memberikan pengaruh yang signifikan terhadap penurunan kadar glukosa darah. Variabel asupan energi memiliki korelasi negatif yang kuat sebesar -0.565 terhadap penurunan kadar glukosa darah. Asupan energi dalam jumlah yang tidak berlebihan dan sesuai kebutuhan dapat mencegah pelonjakan kadar glukosa darah. ${ }^{5}$
Intervensi yang diberikan adalah jus tomat sebanyak 200 dengan kandungan likopen sebanyak 23 gram, protein 1,4 gram dan serat 3,2 gram. Setelah intervensi selama 3 minggu terjadi penurunan kadar glukosa darah puasa sebesar 9,00 $\mathrm{mg} / \mathrm{dl}(7,64 \%)$. Uji statistik menunjukkan terdapat perbedaan bermakna antara GDP sebelum dan sesudah intervensi.

Kandungan likopen pada tomat mampu mengurangi kerusakan oksidatif pada DNA seluler dan mengurangi lemak peroksidasi yang disebabkan oleh penyakit diabetes. Likopen juga dapat meningkatkan konsentrasi insulin, penurunan $\mathrm{H}_{2} \mathrm{O}_{2}$ sehingga dapat berfungsi sebagai antidiabetik. $^{23}$ Selain itu likopen mampu melindungi kerja pankreas dari radikal bebas, sehingga pankreas dapat bekerja secara optimal dalam menghasilkan insulin serta juga dapat menurunkan resistensi hormon insulin, sehingga toleransi sel terhadap glukosa meningkat. ${ }^{24}$

Asupan serat selama intervensi mengalami sedikit peningkatan menjadi 11,39 gram walaupun masih jauh lebih rendah daripada rekomendasi yang dianjurkan yaitu 25 gram $/$ hari. $^{5}$ Menurut berbagai hasil penelitian menunjukkan adanya keterkaitan antara serat pangan dengan penurunan kadar glukosa darah. Serat dapat memperlamban penyerapan glukosa dari usus kecil. Serat pada tomat merupakan serat tidak larut (insoluble dietary fiber) yaitu hemiselulosa. ${ }^{25}$ Serat tidak larut mengurangi proses glukoneogenesis yang berpengaruh terhadap peningkatan sekresi insulin sehingga dapat mengurangi kenaikan kadar glukosa. $^{5}$

\section{KETERBATASAN PENELITIAN}

Keterbatasan penelitian ini adalah menggunakan desain pre eksperimen di mana tidak adanya kelompok kontrol/ pembanding, selain itu tidak dilakukan pengontrolan aktifitas fisik selama intervensi.

\section{SIMPULAN}

Terdapat penurunan bermakna pada uji beda kadar glukosa darah puasa sebelum dan setelah pemberian jus tomat, namun secara validitas eksperimen penurunan glukosa darah puasa dapat disebabkan oleh variabel lain.

\section{SARAN}

1. Penelitian lebih lanjut diperlukan menggunakan kelompok kontrol/pembanding agar hasil yang diperoleh lebih kuat. 
2. Perlu dilakukan pengambilan data aktifitas subjek selama intervensi karena aktifitas fisik memiliki pengaruh yang besar terhadap perubahan kadar glukosa darah.

3. Pada prediabetes dianjurkan untuk melakukan aktifitas fisik dan mengkonsumsi jus tomat karena dapat membantu mengontrol kestabilan kadar glukosa darah.

\section{DAFTAR PUSTAKA}

1. Muchid A. Pharmaceutical Care untuk Penyakit Diabetes Mellitus. Direktorat Bina Farmasi Komunitas Dan Klinik, Departemen Kesehatan RI. 2005. Tersedia dari :URL: http://www.depkes.go.id.

2. Manaf A. Prediabetes. Bagian Ilmu Penyakit Dalam Fakultas Kedokteran Universitas Andalas [serial online][dikutip 22 Agustus 2011]. Tersedia dari: URL: http://www.repository.unand.ac.id.

3. Codario AR. Type 2 diabetes, pre-diabetes, and the metabolic syndrome. Second Edition. Philadelphia, Pennsylvani, USA; 2010. Tersedia dari :URL: http://www.springer.com.

4. Skolnik NS. Insulin Resistance and Pre-diabetes. U.S. Department of Health and Human Services; National Institutes of Health. 2008; 09-4893.

5. Perkumpulan Endokrinologi Indonesia. Konsensus Pengelolaan dan Pencegahan Diabetes Melitus Tipe 2 di Indonesia. Jakarta : PB. PERKENI; 2006. Hal 3-14, 30-31.

6. Whitney E, Rolfes SR, Pinna K. Nutrition and Diabetes Mellitus. Dalam : Understanding Normal and Clinical Nutrition $7^{\text {th }}$ edition. Belmont : Wadsworth; 2002. Hal 790-816.

7. Hastuti RT. Faktor-Faktor Risiko Ulkus Diabetika pada Penderita Diabetes Mellitus; Studi Kasus Di Rsud Dr. Moewardi Surakarta [Tesis]. Program Magister Epidemiologi Universitas Diponegoro Semarang; 2008.

8. Kurnia IA. Manfaat Buah-buahan dan Sayursayuran. Politeknik Kesehatan Departemen Kesehatan Denpasar Jurusan Gizi.

9. Lu W, Simin L, Manson JE, Gaziano JM, Buring JE, Sesso HD. The Consumption of Lycopene and Tomato-Based Food Products Is Associated with the Risk of Type 2 Diabetes in Women. J. Nutr 2006; 136: 620-625.

10. Gartner C, Stahl W, Sies H. Lycopen is More Bioavailable from Tomato Paste than from Fresh Tomatoes. Am J Clin Nutr 2007;66:116-22

11. Maulida D, Zulkarnaen N. Ektraksi Antoiksidan ( Likopen ) dari Buah Tomat dengan Menggunakan Solven Campuran, $\mathrm{n}$ - Heksana, Aseton, dan Etanol [Skripsi]. Jurusan Teknik Kimia, Fakultas Teknik, Universitas Diponegoro. 2010.

12. Marsetyo H, Kartosaputra G. Ilmu Gizi (Korelasi Gizi, Kesehatan, dan Produktivitas Kerja). Jakarta : Rhineka Cipta; 2003. Hal 34-43.
13. Dahlan MS. Statistik untuk Kedokteran dan Kesehatan: Statistik untuk Kedokteran dan Kesehatan: Diskriptif, Bivariat, dan Multivariat, dilengkapi aplikasi dengan menggunakan metode SPSS Edisi 3. Jakarta: Salemba Medika: 2008. Hal 10-13.

14. Rimbawan, Albiner S. Indeks Glikemik Pangan. Jakarta : Penebar Swadaya; 2004. Hal 23-70.

15. Meyes PA. Glukoneogenesis dan Pengontrolan Kadar Glukosa Darah. Dalam: Murray RK, Granner DK, Mayes PA, Rodwell VW. Biokimia Harper $25^{\text {th }}$ edition. Jakarta: EGC; 2003. Hal. 178216.

16. Arthur $\mathrm{C}$, Guyton. Insulin, Glukagon, dan Diabetes Melitus. Dalam : Buku Ajar Fisiologi Kedokteran. Jakarta : EGC; 1997. Hal 1010-28.

17. WHO. Asia-Pacific Perspective : Redefining Obesity and its Treatment. International Association for the Study of Obesity. Sydney: Health Communications Australia Pty Ltd; 2000.

18. Nugroho SA. Hubungan Antara Tingkat Stress Terhadap Kadar Gula Darah Penderita Diabetes Melitus di Wilayah Kerja Puskesmas Sukoharjo I Kabupaten Sukoharjo [Skripsi]. Fakultas Ilmu Kesehatan, Universitas Muhammadiyah Surakarta. 2010.

19. Idamarie L. Nutrition for Weight Management. Dalam : Mahan LK, Stump ES. Krause's Food, Nutrition, and Diet Theraphy $11^{\text {th }}$ edition. Pensylvania : Saunders; 2004. Hal 558-593.

20. Ramachandran A, Snehalatha C. Diabetes Melitus. Dalam : Michael JG, Barrie MM, John MK, Lenore A. Gizi Kesehatan Masyarakat. Jakarta : EGC; 2005. Hal 407-419.

21. Yusharmen. Petunjuk Teknis Pengukuran Faktor Risiko Diabetes Melitus. Direktorat Jenderal Pengendalian Penyakit dan Penyehatan Lingkungan Departemen Kesehatan RI Jakarta. 2008. Hal 7-11.

22. Hadisaputro S, Setyawan H. Epidemiologi dan Faktor-Faktor Risiko terjadinya Diabetes Melitus Tipe 2. Dalam : Diabetes Melitus Ditinjau dari Berbagai Aspek Penyakit Dalam. Semarang : Badan Penerbit UNDIP (PERKENI) : 2007. Hal 133-154.

23. Sari MI. Reaksi-reaksi Biokimia sebagai Sumber Glukosa Darah [Skripsi]. Fakultas Kedokteran Sumatera Utara.2007.

24. Kailaku SI, Sunarmani. Potensi Likopen dalam Tomat untuk Kesehatan. Balai Besar Penelitian dan Pengembangan Pascapanen Pertanian: Buletin Teknologi Pascapanen Pertanian 2007 Vol.3

25. Nainggolan O, Adimunca C. Diet Sehat dengan Serat. Cermin Dunia Kedokteran. 2005 Vol. 51 No. 147 . 